\title{
France's Political and Military Reaction in the Aftermath of the First German Chemical Offensive in April 1915: The Road to Retaliation in Kind
}

\author{
Olivier Lepick
}

\begin{abstract}
Although France had been experimenting with chemical weapons when Germany launched its first lethal chemical offensive in spring 1915 in Langemark, the German initiative came as a huge tactical surprise to the country. Soon after the initial shock and the controversy that ensued on whether Germany had violated the laws of war that day, French authorities rapidly decided, without real political debate, to retaliate in kind. Although the country had to face heavy constraints, and due to a considerable scientific, industrial and financial effort, the French army was able to launch its first drifting cloud chemical attack on the battlefield only a few months after the German offensive. In the storm of the war and at this stage of conflict, when urgency was the only consideration and political influence far less than military, the French authorities did not realize that adopting chemical weapons in retaliation, ten months before Verdun, was one of the steps that would lead to the totalization of warfare and characterize the rest of the Great War.
\end{abstract}

\section{Introduction}

The sudden outburst of chemical warfare initiated by Germany in April 1915, which constituted a deliberate violation of the laws of war, dealt a real shock to French public opinion. Nevertheless, the decision was taken quite soon after to retaliate in kind. The French authorities launched a major industrial and scientific endeavor. And indeed, only a few months after the German surprise attack in Langemark, and despite many obstacles, the French army was ready to launch its first chemical offensive. The purpose of this paper is to describe the first days, weeks and months of the French response to the German chemical initiative, as well as the political and military context in which the decision to retaliate in kind was made by French authorities.

\footnotetext{
O. Lepick $(\bowtie)$

Foundation for Strategic Research, Paris, France

e-mail: olivier@lepick.fr 
The day after the German chemical attack on April 22 in the region of Ypres, a lively polemic broke out between France and Germany, the two protagonists, each blaming the other for unleashing chemical hostilities. German arguments rested in part on the existence of a French note dated February 21, 1915, which gave instructions about the use of suffocating grenades and cartridges. The existence of these materials was confirmed by Ulrich Trumpener in a brilliant article published in 1975 (Trumpener 1975). This article proved, for the first time, and beyond any doubt, that even if the Germans were the first to introduce a lethal form of chemical warfare during the First World War, France had already used non-lethal chemical agents on the battlefield before April 22 (Haber 1986, 32-33; Lepick 1998, 53-66), and, along with Great Britain, the country was already preparing and planning potential military chemical initiatives at the time of the Langemark chemical surprise.

\section{Retaliation in Kind: A Purely Military Decision}

Looking back at the first days following Langemark, the reaction of the French military authorities to the German initiative was tremendously quick. ${ }^{1}$ As soon as April 23, a military pharmacist, Major Charles Didier, who was near Langemark the day of the German chemical initiative, informed the French General Headquarters (GHQ) that the toxin used by the Germans was chlorine. ${ }^{2}$ The same day, Ferdinand Foch, commander of the Northern Army Group, organized a meeting at his headquarters with a renowned French chemist in Cassel, André Kling. The very same day Kling, who was Director of the Paris City Laboratory, started to investigate the issue by visiting hospitals, meeting with victims of chemical weapons, and ordering many post-mortem examinations. As Didier's conclusions about chlorine were rapidly confirmed, Kling immediately began working to develop protective devices for frontline soldiers. On April 24, the first crude orders were issued to field commanders. Foch also asked the Ministry of Industry to provide some input about possible protective devices that could be used by the army, while Paul Louis Weiss, head of the Mines Directorate of the Ministry for Public Works (Travaux Publics), proposed to use the know-how of the mining industry regarding respiratory devices to help the GHQ provide means of defense to the armed forces. ${ }^{3}$

\footnotetext{
${ }^{1}$ It is puzzling to consider that, contrary to the British historiography, there are only very few studies dealing with the French response to the German chemical initiative following April 22, 1915. The only serious study of the history of French chemical warfare during the First World War is the minutes of a lecture that was given in March 1920 by Professor Charles Moureu from the Collège de France, which was later published as: Moureu (1920).

${ }^{2}$ Letter from Charles Didier to the General Commander Army Group Belgium, April 23, 1915, Service historique de l'armée de terre, Vincennes, SHAT/16N826.

${ }^{3}$ Report on the organization of war chemical materials by House Representative Alain Albert d'Aubigny, August 25, 1915, p. 1, Service historique de l'armée de terre, Vincennes, SHAT/16N826.
} 
On April 25 the French Ministry of War decided to begin the production of a crude respiratory protection that was mainly composed of a tissue containing a sort of bag filled with cotton. The device was to be soaked with thiosulfide just before the poisonous cloud reached the first lines, and secured over the mouth in order to neutralize the chlorine before it reached the soldier's lungs. Two days later, the first shipments were leaving for Flanders. By mid-May, more than 500,000 of these protective masks had been distributed to the field.

It is clear that, in contrast to what happened in Great Britain, there were no real political debates at the highest echelons of the French government about whether or not to retaliate. All political authorities were convinced that the decision to retaliate in kind was a military necessity, and proclaimed as one united voice that this kind of warfare was simply abhorrent. French military authorities found absolutely no opposition to their willingness to retaliate. Less than 48 hours after the German offensive in Langemark, military and political leaders had agreed on the fact that the country was to respond to the German initiative as soon as possible. ${ }^{4}$ Nevertheless, how can we explain the absence of political input concerning such an important decision, especially since the use of new weapons that could lead to political consequences was strictly controlled by the civil political authorities? Initially, at this point in the conflict and up to the dismissal of Alexandre Millerand as Minister of War in October 1915, the French government's policy was not to interfere in the conduct of the war. At no other point during this conflict had the French GHQ enjoyed such great room for maneuver, such independence from political influence. Furthermore, the French government deemed that the German attack had liberated France from its obligations accruing through its signature to the Hague Convention. From a governmental perspective, the decision to retaliate in kind was purely technical and military and fully in within Foch's ambit. And Foch's decision was taken a few hours only after the April 22 attack. On April 25, General Maxime Weygand captured the general opinion in the country by stating:

The Germans took the initiative to use inhuman means of warfare that had been banned by international treaties. But for us, it was not about procedures but about preparing as fast as we could the means to protect ourselves and retaliate in kind to these attacks [...]. A new step toward total warfare has been taken by our enemies. ${ }^{5}$

On April 26, the Ministry of War asked all French chemical companies to report the amount of chemicals in their stocks which could be used to respond to the German initiative. $^{6}$

\footnotetext{
${ }^{4}$ On this subject, the following books are highly valuable: Joffre (1932); Poincaré (1930, 173, 350).

${ }^{5}$ Les Allemands avaient pris l'initiative d'un moyen de lutte inhumain et condamné par les accords internationaux. Mais il ne s'agissait pas pour nous de procédures, il fallait sans retard trouver à la fois contre ces attaques, la protection et la riposte [...]. Un nouveau pas venait d'être fait pas nos adversaires dans la pratique de la guerre totale (Weygand 1953, 225). Translation by the author. ${ }^{6}$ Buat Archives, Service historique de l'armée de terre, Vincennes, SHAT/6N21; Dossier 18, Ministry of War, Notes on the measures adopted following the use of asphyxiating gases by the enemy on April 28, 1915.
} 
Finally, on June 2, 1915 the French government published a press release for the attention of foreign countries. Starting with a vigorous denunciation of the awful techniques used by the German army, which violated all of the treaties signed by the Imperial government, the release closed with the statement that

no government shall not respond to such barbarian initiatives without endangering its own troops. In this perspective, the French government intends, in the strict limits of its military needs, to use all necessary means that appear appropriate to stop the German military authorities from continuing to commit such horrible murders [...]. (Le Temps, 1915)

\section{Between Eagerness and Constraints: Organizing the Chemical Response}

On April 26, a note from the GHQ was transmitted to all armies. The memorandum summarized the outcome of the interrogation of German prisoners captured near Bixschoote two days earlier. This short text described the defensive measures to be taken in case of gas attacks, and was intended to comfort the troops by stating that "a tissue soaked with the liquid that was distributed on the front lines or even one soaked with water could easily protect the soldiers against these toxic gases."7

Very rapidly, the French authorities built the organization charged with directing the national chemical retaliation program. ${ }^{8}$ As soon as April 28, a committee composed of both military and scientific representatives was installed under the command of Paul Louis Weiss. Days later, three different organizations were created:

- One commission headed by Kling, tasked with identifying the chemical agents used by the enemy,

- a second headed by Weiss in charge of offensive aspects,

- and a third dedicated to the production of chemical agents, which was headed by the Engineer Corps.

On April 30, the first live experiments with non-toxic fumes took place at the proving ground in Satory (15 km southwest of Paris). On May 4, the first attempt to produce a chlorine cloud was conducted, with limited results. As liquid chlorine was difficult to obtain in the country, other products had to be considered. On June 2, 1915, Weiss, as head of the Commission des Etudes Chimiques de Guerre proposed a tentative organization for the military chemical services. He proposed the creation of a completely new directorate attached to the Ministry of War. This proposition was not backed by Albert Thomas, under-secretary for artillery and

\footnotetext{
${ }^{7}$ Note to the Armies by General Pelle, Les Armées Françaises dans la Grande Guerre, Ministère des Affaires Étrangères, Paris, 1922-1939, vol. 2, Annexe $\mathrm{N}^{\circ} 1451$, p. 1017.

${ }^{8}$ The organization of the French chemical warfare services is described very precisely in: Vinet (1919, 1377-1415).
} 
munitions, who wanted to extend his department's responsibilities to chemical warfare. Nevertheless, a consensus was found, and on June 18 a Directorate of Chemical Material (DCM) was installed under Weiss's command. ${ }^{9}$ The scope of this DCM's duties was limited to research and development.

In July 1915 a group of representatives requested the creation of a new independent directorate under the Ministry of War. In accordance with the proposal from the GHQ, a colonel named Paul Ozil was promoted to head up this now fully independent DCM, placed in charge of all aspects of chemical warfare for the Ministry of War. Its internal structure remained unchanged until the end of the conflict, consisting of the three different commissions created a few days earlier: R\&D, materials, and production. ${ }^{10}$ Military camps and proving grounds were soon dedicated to chemical trials, in Satory for the protection of individuals and for small gas emissions, in Fontainebleau for artillery tests, and in Vincennes for explosives and structural tests. One of the first possibilities explored by French researchers was aerial chemical bombing. On June 10, the GHQ suggested to the Ministry of War that "airplanes could be an interesting means to deliver chemical weapons, especially in counter-artillery operations in hidden areas."11 The initiative was given to General Fernand-Alexandre Curmer, yet rapidly led to the conclusion that, due to the limited amount of toxins that an airplane could carry, the use of airplanes to deliver chemical attacks bore little potential. During the same period, the GHQ was trying to develop measures to improve defenses against drifting chlorine clouds. On May 28, a first order was delivered to all armies, containing instructions for protective measures, but also describing methods to disseminate the clouds by artillery fire- thus exposing the lack of any real solution to respond to this new technology with military means. ${ }^{12}$

\section{Chemical War: Scientific War, Industrial War}

At the time Germany initiated chemical warfare, France was not in a position to fight and respond to the attack. The Germans were aware of this situation. The French chemical industry and its production were meager, and so were its capacities to produce chlorine, bromine and sulfuric acid. The French military chemical organization had to invest an immense amount of work and resources in order to

\footnotetext{
${ }^{9}$ Report on the organization of war chemical materials by House Representative Alain Albert d'Aubigny, August 25, 1915, p. 1, Service historique de l'armée de terre, Vincennes, SHAT/16N826.

${ }^{10}$ Letter from the Commander in Chief to the Defense Minister, July 21, 1915, Service historique de l'armée de terre, Vincennes, SHAT/16N832.

${ }^{11}$ “Chemical Shells, 18 septembre 1914-28 septembre 1915," Note from GHQ, June 10, 1915, Service historique de l'armée de l'air, Vincennes, Cartons A54, Dossier 1.

${ }^{12}$ Instructions established by the North Army Corps concerning defense against toxic gases, May 28, 1915, Service historique de l'armée de terre, Vincennes, SHAT/6N7.
} 
provide the French Army with compounds that could be militarized. French chemists rapidly realized that domestic chlorine production capacity was so low that months, or even years, would be needed before a counterstrike could be launched. The possibility was investigated nevertheless, and live tests with chlorine were conducted in May, June and July. Because of the absence of a real chemical industry, French researchers were obliged to turn to other compounds, and delivery methods other than drifting clouds, rather soon reaching the conclusion that artillery was probably the best means of delivery to deploy chemical agents. The first agent available was carbon tetrachloride, which was easy to synthesize. The first promising trials were conducted on the Vincennes Proving Grounds in May and July 1915. As soon as August, Joffre approved production of a first batch of 50,000 shells containing carbon tetrachloride. ${ }^{13}$ The shell received the code name "Obus $N^{\circ} 1$ "; more than 420,000 were produced and then used in September during the French offensives in Champagne. ${ }^{14}$ Nevertheless they were rapidly abandoned due to their lack of efficiency and low toxicity.

This apparent conclusion about the efficiency of artillery shells to deliver chemical agents by French military researchers can probably explain the ineffective performance by the first units, called "Compagnie Z," formed to prepare and execute drifting cloud chemical attacks. During summer 1915, two units of 800 non-combat troops were created, and three more in June 1916. These units were to conduct all 51 of the drifting chemical cloud operations that the French Army would launch during the war, the first of which took place in mid-February 1916, more than 10 months after the first German chemical attack (Lepick 1998, 133174). Many other compounds were under close study by French researchers. The first agent the French researchers seriously planned to militarize was phosgene, one of the very rare toxic chemicals that was produced in large quantities in France. A limited production of shells containing hydrocyanic acid was ordered in June 1915, but surprisingly enough, the French government decided to postpone their immediate use. Because these shells were undoubtedly lethal due to the high toxicity of hydrocyanic acid, their deployment would have represented a clear and obvious violation of the 1899 Hague Convention, which prohibited the use of toxic shells. These shells, the first real lethal ones shot during the Great War, were used only during the battle of Verdun in February $1916 .^{15}$

France, whose chemical industrial capacity was very limited, undertook a massive industrial effort. In 1915, only Germany had a real chemical industry in terms of not only size, but know-how, agility and resources. Before the war France was completely dependent on German imports of liquid chlorine and bromine. These imports came to sudden halt, of course, as soon as war broke out.

\footnotetext{
${ }^{13}$ Memorandum on the use of poison gas in warfare by General Curmer, Service historique de l'armée de terre, October 1st, 1915, Vincennes, SHAT/16N839.

${ }^{14}$ Memorandum on the constitution of special units for the use of $\mathrm{Z}$ equipment, December 23 , 1915, Service historique de l'armée de terre, Vincennes, SHAT/16N826.

${ }^{15}$ Secret message from the GHQ, February 18, 1916, Service historique de l'armée de terre, Vincennes, SHAT/16N707.
} 
The challenge was for France to create adequate industrial capacity ex nihilo. The first demands for chlorine were covered by imports from Italy and mostly Great Britain. In early September, French authorities negotiated the acquisition of more than 50 tons of liquid chlorine per week from the Runcorn production facility, ${ }^{16}$ the first batches of which arrived in France in October. The production capacities available for export in the UK were nevertheless far lower than those needed to supply a French military program. French authorities were forced to launch an ambitious industrial plan to build production facilities all over the country. As early as August 1915 a first industrial program was launched, planning the construction of six different chemical plants able to produce 30 tons of liquid chlorine a week. In early 1917, French liquid chlorine production capacity topped a level of 50 tons a day, a large share of which was produced in privately owned companies. For bromine, the problem was even worse, as Germany had a monopoly on bromine production in Europe. First supplies were imported from the United States as soon as June 1915. A solution emerged when a subterranean lake was discovered $600 \mathrm{~km}$ south of Tunis in Tunisia, at that time a French colonial possession, from which bromine could be extracted. A factory was built and began production in April 1916, yielding more than 900 tons of bromine during the war, plenty enough to fulfill the country's needs (Bloch 1926, 32).

Because of these industrial difficulties, the first French attack with drifting chlorine clouds did not take place until February 1916. The French conducted more than 50 such attacks, mostly during 1916. Some of them were massive, conducted on a front line more than $8 \mathrm{~km}$ long, and supported by more than 6,000 pressurized cylinders containing almost 300 tons of chlorine per operation. ${ }^{17}$ The French rapidly abandoned this technique, for obvious reasons such as heavy meteorological constraints and early adoption of artillery as the main delivery system for chemical weapons, probably one of the most extraordinary offensive means of operation during World War I.

\section{Retaliation in Kind: Towards Total War}

The sudden outburst of chemical warfare initiated in April 1915 by Germany, which deliberately violated the laws of war, truly shocked the French public. Nevertheless, the decision was taken very rapidly by the French government to retaliate in kind, which entailed a huge industrial and scientific effort. And indeed, only a few months after Langemarck, the French army had surmounted many obstacles and was ready to launch their first chemical offensive. Great Britain was

\footnotetext{
${ }^{16}$ Letter from the 4th Directorate of the Ministry of Defence to the GHQ, October 17, 1915, Service historique de l'armée de terre, Vincennes, SHAT/16N827.

${ }^{17}$ General Curmer's archives. Service historique de l'armée de terre, Vincennes, SHAT/16N903.
} 
able to launch the first allied chemical attack, on September 15, 1915 in Loos, followed by France in February 1916.

The scientific, industrial and financial effort was extraordinary for both countries, especially considering the starting point for France. But in the storm of the war, when urgency was the only law and political influence far less than military, the French authorities did not realize that by adopting chemical weapons in a mechanical way, as they did, they unconsciously took a first step leading to total war. Of course at that period of the conflict, gas was not yet a weapon of annihilation, but rather the weapon that promised local breakthroughs from the deadlock of trench warfare (Joffre 1932). This perspective was so crucial that political authorities stood aside. But, undoubtedly, ten long months before the battle of Verdun, the beginning of gas warfare was the first real step toward the totalization of the war.

\section{References}

Bloch, Paul. 1926. La guerre chimique. Revue militaire française 21: 19-47.

Haber, Ludwig F. 1986. The poisonous cloud: Chemical warfare in the First World War. Oxford: Clarendon.

Joffre, Joseph. 1932. Les mémoires du maréchal Joffre. Paris: Plon.

Lepick, Olivier. 1998. La Grande Guerre chimique 1914-1918. Paris: Presses Universitaires de France.

Les Armées Françaises dans la Grande Guerre, Ministère des Affaires Étrangères, Paris, 19221939.

Le Temps. Le gouvernement français répondra à l'emploi des gaz asphyxiants. June 2, 1915.

Moureu, Charles. 1920. Chimie de guerre, les gaz de combat. Paris: Librairie de l'enseignement technique.

Poincaré, Raymond. 1930. Au service de la France: 1915, les tranchées. Paris: Plon.

Trumpener, Ulrich. 1975. The road to Ypres: The beginning of gas warfare in World War I. Journal of Modern History 47: 460-480.

Vinet, Emile. 1919. La guerre des gaz et les travaux des services chimiques français. Chimie \& Industrie 11-12: 1377-1415.

Weygand, Maxime. 1953. Idéal vécu. Paris: Flammarion.

Open Access This chapter is licensed under the terms of the Creative Commons Attribution-NonCommercial 2.5 International License (http://creativecommons.org/licenses/by-nc/ $2.5 /$ ), which permits any noncommercial use, sharing, adaptation, distribution and reproduction in any medium or format, as long as you give appropriate credit to the original author(s) and the source, provide a link to the Creative Commons license and indicate if changes were made.

The images or other third party material in this chapter are included in the chapter's Creative Commons license, unless indicated otherwise in a credit line to the material. If material is not included in the chapter's Creative Commons license and your intended use is not permitted by statutory regulation or exceeds the permitted use, you will need to obtain permission directly from the copyright holder. 